DEPARTMENT OF INTERNATIONAL RELATIONS

Working Paper 2001/1

\title{
RELATING GLOBAL TENSIONS: \\ MODERN TRIBALISM AND \\ POSTMODERN NATIONALISM
}

Paul James 
Canberra, June 2001

National Library of Australia

Cataloguing-in-Publication Entry

\section{Paul James}

Relating global tensions: Modern tribalism and postmodern nationalism ISBN 0731531094.

1. I. Australian National University. Dept. of International Relations.

II. Title. (Series : Working paper (Australian National

University. Dept. of International Relations) ; 2001/1)

327.07051

(C) Paul James 


\section{DEPARTMENT OF INTERNATIONAL RELATIONS \\ Working Papers}

The department's working paper series seeks to provide readers with access

to current research on international relations. Reflecting the wide range of interest in the department, it will include topics on global intemational politics and the international political economy, the Asian-Pacific region and issues of concern to Australian foreign policy.

Publication as a 'Working Paper' does not preclude subsequent publiccation in scholarly journals or books, indeed it may facilitate publication by providing feedback from readers to authors.

Unless otherwise stated, publications of the Department of International Relations are presented without endorsement as contributions to the public record and debate. Authors are responsible for their own analysis and conclusions. 


\section{ABSTRACT}

What is the relationship in the contemporary world between the abstract global 'peace' of state-initiated violence from above, and the embodied violence of persons hacking into others with machetes as they lay on the ground? Can this be explained simply in terms of the difference between the rationalising modern nation-state and resurgent tribalism? This essay explores the contradictions associated with peace and violence in a globalising-localising world, both generally and in relation to violence in Rwanda and Bosnia-Kosovo. The essay is intended predominantly as a political essay opening up lines of understanding. It argues that the postmodernists hope that postnationalism will offer a way out of the mess is thoroughly misplaced. This is particularly so given that those states that swept militarily into Kosovo from above, now project themselves across the globe with the same new enthusiasm for pax postnationalism as the postmodernists themselves. 


\title{
RELATING GLOBAL TENSIONS: MODERN TRIBALISM AND POSTMODERN NATIONALISM
}

\author{
Paul James
}

We live in confusing times. One of the dominant trends in the present period is the deepening of a set of social contradictions that have only been generalised for a couple of generations. On the one hand, globalisation, a process with long historical roots, has been developing at an unprecedented pace through the end of the twentieth century and into the new millennium. A rough, uneven blanketing of capital and commercial culture crosses and connects the world in unprecedented ways. On the other hand, there is an intense fragmenting and reconfiguring of social relations at the level of community and locality. Systemic processes of rationalising homogenisation integrate the globe at one level, while ideologies and practices of difference and radical autonomy frame the popular imaginary at another. On the one hand, globalisation carries a structure of disembodied 'peace', tragically defended through strategic defence systems and undeclared technologically mediated wars. On the other hand, the era of globalisation is beset by embodied violence in a thousand trouble spots. These are material and lived contradictions rather than simply inexplicable paradoxes. They need to be explained.

It is not that we fail to recognise the surface expressions of these contradictions. In their immediate expression we see them quite dramatically. At the

1 School of Political and Social Inquiry, Faculty of Arts, Monash University. Paul James is an editor of Arena Journal and teaches politics at Monash University. His books include Nation formation. Towards a theory of abstract community (Sage, London, 1996), The state in question: Transformations of the Australian state (Allen \& Unwin, St Leonards, 1996), and Work of the future: Global perspectives (Allen \& Unwin, St Leonards, 1997). 
about the end of good old-fashioned national pride. 
between different senses of locale in the global village. In Australia and New Zealand, the worldwide franchiser of hamburger outlets, McDonalds, began an advertising campaign explaining how each of its franchisees will organise local community noticeboards. ${ }^{5}$ In Cambodia, the 'Japanese' car manufacturer Toyota ran a campaign under the banner headline 'This is Our Town'. To the backdrop of a photograph of planet earth spinning in space, the patronising copy speaks with postcolonial sophistication of the peaceful mutuality of the global project. All the while it slips between different meanings of the 'local' and the 'we':

It's the global village. We live here. You do, too. We're neighbours. And since we're neighbours, we should be friends. It seems that we are all of us everywhere-slowly coming to this realization. But how do we do it? In a practical sense what steps do we take? We can't speak fr others, but for ourselves we can say this: we will do our part to bring the world together by building up the global auto industry ... For the first half of the century we thought of ourselves as a Japanese company ... Now we think of ourselves as a world company. Our responsibility is to everyone Cambodia Daily 13 July 1994).

Despite this self-conscious commercial-political emphasis on the intersecting trends of globalism and community, and despite its embeddedness in everyday life, we still have a poor understanding of the structures, systems and institutions that in the age of disembodied globalism both integrate polity and community and simultaneously threaten to break them apart. Very little work, for example, has been done on the relationship between abstract 'peace' at the global level and continuing embodied violence on the ground. Social theorists over the past decade have made globalisation and localism a constant point of reference. However, in turning to ugly concepts such as 'glocalisation', defined as the simultaneous globalising and localising of social

5 The continuing tension here with McDonalds still seen to be a pre-eminently global corporation is exemplified by the violent targeting of one of their outlets in Davos at the 2000 World Economic Forum. Going back further, in 1985, London Greenpeace organised an International Day of Action against McDonalds. Leaflets were distributed, which over the next few years became the basis for a libel trial that was to take two-and-a-half years, concluding in June 1997. The action taken against two community activists in London became known as the McLibel Trial. 
relations, they have named the processes that need to be worked through rather than given us the tools with which to do so. Roland Robertson notes that the concept of 'glocalisation' comes rom the Japanese word dochakuka, originally dochaku, which means 'living on one's own land' (Robertson 1992: 173-4). 6 However, dragged into the context of global micro-marketing campaigns such as 'This is Our Town', the term came to be instrumentalised as the act of adapting locally to meet global circumstances. This in itself should have given pause for thought, but nevertheless the term quickly became part of the social theory lexicon as an easy shorthand concept for an extraordinarily complicated phenomenon. It is not so different from the way in which the Finnish concept of embodiment, kännykkä, 'extension of the hand', used as a Nokia trademark for their mobile telephone, subsequently passed into the generic parlance of Finnish teenagers as the word for phone (Silberman 1999). ${ }^{7}$ It is the process that underlies these etymologies that this essay is interested in -the stretching between the concrete and the abstract. The embedded and grounded meaning of the terms themselves-living on one's own land, extension of the hand-carry us metaphorically into the contradictions of our time. Expressions of the abstraction of our relationship to others are often carried in the relatively concrete language of the body and of grounded place. These then are the themes of his essay: globalism and localism, disembodiment and embodiment, abstract peace and embodied violence. While attempting to connect these themes in a way that does not set up related terms as dichotomies, the undercurrent of the essay is conducted as a critique of those writers who make the modern nation-state per se the source of the problem, or its demise into postnationalism or postmodern cosmopolitanism the source of redemption. In so arguing, I have no intention of defending either modernism or the nation-state. However, in the face of abstract globalism, you'll find hints of a political position that

6 In the early 1990s, Robertson used the concept advisedly. However, by the middle of the decade it unreservedly took a centreplace in his writings (Robertson 1995).

7 In 1998, of 165 million mobile phones sold in the world-that is, more mobile telephones than cars and computers combined-Nokia manufactured 41 million units. 
cannot be developed here-one that defends the importance of reflexive, critically negotiated and embodied community. ${ }^{8}$ The essay begins with a discussion of the arguments about postnationalism, establishing some working definitions to help make sense of the problems of understanding the relation between nationalism, globalism and tribalism. It then turns to studies of Rwanda and Kosovo as settings through which to elucidate those problems.

\section{A POSTNATIONAL WORLD?}

For many of those writers caught up in the heated discussion of globalism and localism, the future of nationalism has been reduced to the globally produced local expressions of individuals experiencing mobile, hybrid and diasporic identities. This kind of identity formation is increasingly called 'postnationalism' (Appadurai 1996: chapter 8). According to the literature on the subject, postnationalist individuals -in-mutual-exile may seek 'communal' connection but it is not on the basis of an underlying attachment to territorial foundations. It is as loosely configured imagined community that may or may not have continuing embodied ties. In this view the defence of territorial and blood ties is seen as the primary source of continuing violence in the modern world. Postnationalism, they say, thus offers a positive way out of the territorially bounded and restrictive politics of the bad old nation-state. In fact, most of these writers go further to announce the imminent irrelevance of the existing system of modern nation-states. It is blithely presented as a fait accompli: 'the nation-state', says Arjun Appadurai, 'has become obsolete' (1996: 169). ${ }^{9}$ Rather than engaging in a lengthy critique of this position let me just note three counterpoints.

8 See the article (James 1999/2000) that originally came out of my contribution to the Academica Sinica conference organised by Alan Chun. The present essay draws on material presented there.

9 The quote comes from Appadurai but the sentiment ranges widely from post modernists to radical liberals: for examples of the latter group, see from the Left, Guéhenno (1995) and from the Right, Ohmae (1996). 
Counterpoint 1: Postnationalism is presented as a novel development of the turn of the millennium. In some quite specific ways (though some significant qualifications will be raised in a moment) we can agree that it does represent a new pressure on the modern nation-state. However, it has to be recognised that modern nationalism continues to be expressed at the political-institutional level through social movements of compatriots acting in concert to achieve a singular nation-state. Moreover, these nationalisms are ironically often the response to the same disruptions of globalism that produce postnationalism. By the same argument, modern nation-states continue to be relevant to contemporary social relations, despite-indeed sometimes because ofnational responses to modern and postmodern crossings of their borders. The obvious example is the heightened regulation of embodied movement: the national regulation of refugees and emigrants.

Counterpoint 2: The kind of postnationalism being described by some postcolonial writers is only one form of a number of different kinds of postnationalism. In fact I will go further and suggest that the diasporic kind of postnationalism highlighted by the postcolonial and postmodern writers do not represent the most novel form of postnationalism at all. The postcolonial identity of the person who has moved along the tracks of globalism has stronger continuities with past forms of hybrid assertions of identity than do the new postnationalisms of the capitalist West. A read of Benedict Anderson (1991) on the creole elites of eighteenth-century Latin America, or Eric Wolf (1982) on the mobile Turks of the medieval Silk Road, substantially qualifies any sense that hybridity is a postmodern let alone uniquely recent phenomenon. By contrast, state-based postnationalism has few continuities with past forms of political legitimation. When late-modern states such as the United States of America present themselves as simultaneously national and postnational it suggests that the sensibility of postnationalism needs to be understood in much broader terms than hybridity.

Counterpoint 3: Postnationalism is most often projected normatively as a positive kind of postmodern cosmopolitanism-as multiple or displaced attachments to others in exile. Against this projection I argue that it is done 
without any obvious exploration of what is a good way of living. ${ }^{10}$ In either of these moves-either to advocate postnationalism or postmodern cosmopolitanism-past forms of solidarity such as the modern nation tend to be reduced to clichés: for example, in Appadurai's words, 'As the ideological alibi of the territorial state, [the nation] is the last refuge of totalitarianism' (1996: 159). By the same move, solidaristic attachment and relatively bounded and embodied placement, come to be described as part of the problem. Appadurai writes: 'As I oscillate between the detachment of a postcolonial, diasporic, academic identity (taking advantage of the mood of exile and the space of displacement) and the ugly realities of being racialized, minoritized, and tribalized in my everyday encounters, theory encounters practice' (1996: 170). This appears to treat displacement and exile as a simple opportunity to detach (at least for the privileged), rather than as a vexed dialectic of abstracted insight and more concrete loss. I will explore these arguments in more detail in two case studies on Rwanda and Bosnia-Kosovo, but before doing so we need to establish some definitions.

\section{DEFINING GLOBALISM, NATIONALISM AND TRIBALISM}

Globalism appears to be the easiest concept in the world to define. In one way it is simply the extension of social relations across the global space. It is literally evoked in the picture that we have become accustomed to seeing in satellite photographs. However, that definition leaves us concentrating on the last few decades. An alternative working definition of globalism begins from a method that relates the various intersecting modes of practice to their extension across world-space. As historically these practices have become more abstract, globalism as a manifold of those connections has, because of its increasingly disembodied character, become both more extensive and more intensive. There are, however, earlier forms of globalism that need to be

10 Bruce Robbins (1998: 3) represents a critical cosmopolitanism that largely avoids the valorisation of mobility and detachment endemic in postmodern cosmopolitanisms, but in criticising its critics he occasionally falls off the balancing beam. Cheah (1998) turns the critique back on the postnationalists, convincingly arguing that cosmopolitanism need not be postnational. 
incorporated into any definition. There are lines of global connection carried by agents of the early expansionist imperial states, by traders on the silk routes, and by crusading war-makers going off to smash the infidels simply because they were there living in the same world. At this stage 'smashing the infidels' meant civilising them by means of sword and burning oil, not engaging in genocide. ${ }^{11}$ Thus globalism is defined as the uneven but structured manifold of connections across world-space, taking that space in the historically variable terms that it has been socially understood through changing world-time, and understanding the matrix of connections as materially enacted through one or more of the various dominant modes of practice: exchange, production, communication, organisation and enquiry. ${ }^{12}$

The definition then is sensitive to the position taken by Robertson (1992) that globalism is a deep historical and variable process. ${ }^{13}$ With Robertson it fundamentally questions modernists like Anthony Giddens (1990) who suggest that globalism is a consequence of modernity, and utterly rejects the position of theorists such as Martin Albrow (1996) who claim that globality is now replacing modernity. Giddens, in this view, does not lave more than a single-layered sense of history, and Albrow makes a fundamental category mistake: modernism and globalism are two different categories of social formation. Processes of globalisation developed before modernity (understood only provisionally in epoch terms) and will probably continue long after it, but this does not mean that globality is replacing modernity. It means that the form of globalism is changing, as is the once assumed dominance of modernism, and before that of traditionalism. In the early forms of traditional

11 Compare this to the argument later in the essay on genocide in Rwanda.

12 As Kate Cregan has pointed out to me the word 'matrix' carries in its multiple meanings the contradictorily embodied/disembodied nature of abstracted social relations that the present study is attempting to describe. Its most general meaning is a setting in which something takes form, has its origin or is enclosed. In obstetrics 'matrix' refers to the body of the womb. By contrast, in mathematics it refers to a regularised array of abstract elements. And in engineering (my personal favourite given the current expressions of globalism) it refers to a bed of perforated metal placed beneath an object in a machine press against which the stamping press operates.

13 Robertson's historical mapping of the 'phases' of globalism is the subject of chapter 3 in that book. 
globalism, from perhaps the Roman Empire through to the modern mercantile globalism of the seventeenth and eighteen centuries, the connections were carried as lines of agency through a landscape that, except for imperial centres of intensity, still sustained traditional-localised forms of social life. However brutal colonisation was, it tended, despite 'civilising' intentions to the contrary, to overlay and reconstitute rather than completely destroy traditional forms of life. In the contemporary period, the globalism is much more than lines of interconnection. It is carried as a plane of connections. Like earlier forms of globalism, this layer does not completely transform all before it, but unlike the past it does blanket various social forms of community and polity with the effects and imperatives of disembodied modes of practice: commodity and financial exchange, computerised production, electronic communication, techno-science and so on. This blanketing can no longer be passively ignored with the hope that it will go away, if it ever could.

If it is possible to conceive of traditional, modern and postmodern forms of globalism, the same can be said of tribalism. By comparison, nationalism, even when it draws on the content of tradition, does not have a history going back prior to modernity. Part of the problem of defining terms such as tribe and nation, and related concepts of affinity such as ethnicity and race, derives from our increasing selfconsciousness that the boundaries of these terms of relationship get more and more blurred as we turn our analytical microscopes on the specificities that were once said to define the boundaries of actually existing communities. It used to be, and often still is the case, that without thinking much about it, commentators took the particularities of embodied difference as the essentialised markers of the edge of an ethnic or racial grouping. They then made, make, ethnicity one of the central factorsalongside other commonalities such as those of language, history and territory-through which members of one nation can be distinguished from another. Along these lines, race is seen unproblematically as a genetic category, ethnicity is seen as an extension of kinship and inhering in the body of the person as born ethnic, and the nation is seen as an extension of ethnicity as the most important variable factor of cultural commonality. Thus nation-states are understood to be formed in the tension between the unchosen identity of kinship-ethnicity and the daily plebiscite (Renan) of 
chosen civic identity. This is not entirely a caricature. Parts of that picture can be retrieved, but its terms need to be rethought.

In parallel with the problematising of the area of ethnicity studies, anthropological research found that kinship relations, one of the defining conditions of tribalism, could be formed of real or fictive blood-ties. This leads to an overturning of many of the taken-for-granted assumptions about what constituted a tribe. It led to much confusion, ranging from inappropriately applying tribalism to all situations of seeming primordial intensity such as the Balkans, to pronouncements that the word is too politically charged to use at all. Unfortunately such a response gives us no place to stand. Are then tribes a modern invention? Answering 'no' brings us much closer to the complex truth than saying 'yes'. The concept of 'tribe', I suggest, names real, selfreproducing and changing communities living in the world today. Making the issue more complicated, it is possible to have tribalism beyond traditional tribes. As a way out of the problem, tribalism is treated here as an ontological formation. The treatment carries none of the connotations of the original dichotomy: 'tribal' = 'simple and primitive' whereas ethnic or national $=$ 'modern and complex'. Tribalism is defined, most generally, as the framing condition of a certain kind of community in which persons are bound beyond immediate family ties by the dominance of modalities of face-to-face and object integration, including genealogical placement, embodied reciprocity and mythological enquiry. Furthermore, as tribal communities have fundamentally changed across modern history we have to treat tribalism as an ontological formation that is most often now framed in intersection with other formations. A few examples will give a sense of the diversity of possibilities. The Tutsi, as once the royal genealogy of a pre-colonial kingdom that formed on the flat grasslands of Rwanda's Lake Mohasi, are now a modern tribe-caste intent on nation building. The Jews, as once the twelve tribes of Israel, are now spread across the globe as variously a diaspora nation an ethnicity and a religious creed. And the Campbells, as once the tribal clan bound to Glenorchy, are now simultaneously actual families, a globally disconnected national family name spread by the waves of emigration, and the sign of abstract kilted nostalgia. Such examples give a sense of the kinds of complexities that have to be taken into account. As a 
way of handling this, it is proposed that definitional distinctions should be drawn between different kinds of tribalism: traditional tribalism, modern tribalism or postmodern tribalism. Under this definition the Jews of Israel and the Campbells of Scotland can no longer be considered tribes as such, even though they sometimes embrace the subjectivities of tribalism. ${ }^{14}$ This approach thus treats tribal community as fundamentally different from abstracted community of the nation, even if the nation sometimes draws on some of the same ideologies of kinship and blood ties. It criticises the loose, ideologically charged use of the concept of 'tribalism' to describe the internal break-up of the postmodern nation-state or to distance civic nationalism from the primordial intensity of situations of violent national conflict. Carolyn Marvin's messy use of the metaphor of tribalism to explain the blood sacrifices of the American nation-state, discussed later, leaves us understanding less about the contemporary Lhited States than about how contemporary intellectuals often completely misunderstand the complexities of actual tribalism (Marvin and Ingle 1999). ${ }^{15}$

\section{PROBLEMS OF UNDERSTANDING: MODERN TRIBALISM TO POSTNATIONALISM}

In order to introduce some of the problems of explanation that haunt the study of tribalism, nationalism and globalism, it is instructive to take a couple of examples of community-polities in flux. In some ways, the two examples chosen could not be more different, but there is much in them that overlaps including the themes of globalism, nation-building and changing forms of identity. One example is the modern tribalism of Rwanda caught between traditionalism and modernism as it descended into a postcolonial hell of genocide against the Tutsi. In 1994, about 800,000 people were killed in one

14 On the process of transformation in Scotland, for example, see Dodgshon (1998). That the Campbells are no longer a tribe does not mean that tribalism is now only confined to 'residual' groups in the Third World.

15 The methodological approach of Marvin and Ingle's book will be critically examined later in the essay. 
of the most horrific periods of concentrated slaughter in recent history. ${ }^{16}$ Nearly two million people fled as refugees. It was a period with some parallels to the Nazi holocaust and the attempted genocide of the Jews. The other example is the nationalist violence in the Old Yugoslavia as the postnational war-machines of the United States of America and the United Kingdom attempted to extricate themselves from a war that was never declared. What I hope to open up in these examples is a threefold complication. The first complication is that in contemporary society different ontological formationstribalism, traditionalism, modernism, postmodernism—overlay each other in ways that always disturb, and in some cases completely fracture, the kinds of ontological security sustained through their very different forms of social identification and political organisation. The second complication is that this violent fracturing of felt-security is bound up with the contradictions generated between embodied ways of experiencing the self and the layers of more materially abstracted processes of social formation. I am not suggesting that the intensification of these contradictions always, or even mostly, leads to social breakdown and violence. At the other extreme, the intensification of contradiction can under certain conditions sustain a rationalised indifference to difference. ${ }^{17}$ However, indifference, either passive or cold-blooded, was certainly not the outcome in Rwanda. The point of dwelling upon an episode such as the 1990s' genocide is that we can see the process of intensifying contradictions most starkly when people's sense of ontological security is so fractured. The third complication is that the violence in Rwanda does not stem from a reversion to traditional tribalism but from the long-term effects of modern globalisation. In a parallel argument in the section on Bosnia-Kosovo

16 Among the many articles and books now written on Rwanda, I am particularly indebted to Mamdani (1996) and Prunier (1997). The figures are all approximations, but I have cross-checked multiple sources. For a good overview of dher relevant literature see Johnston (1998).

17 See Herzfeld (1992). This 'indifference' can itself in turn can become the basis of state-legitimised violence from a distance. Rationalised violence, as evidenced in the wars over Iraq and Kosovo, is however usually framed at a more abstract or technologically mediated level. In practice, of course, war is fought across the various levels of embodiment to disembodiment, but the framing of war has become increasingly abstract over the course of history even if the flesh-andblood bodies of civilians increasingly bear the brunt of military action. 
Paul James

I will suggest that the United States' intervention from above cannot be explained simply in terms of classical nationalism but is related to the emerging contradictions of postnationalism in a globalising world.

\section{VIOLENCE IN RWANDA: FROM NATION-BUILDING AND MODERN TRIBALISM TO GENOCIDE}

On 6 April 1994, an aeroplane carrying the Rwandan and Burundi presidents was shot down over Kigali. The incident became the apparent trigger for a state of genocide that would see approximately onetenth of the population murdered over the period of a few intense weeks. Eighty per cent of the victims of the Rwandan genocide, most of them Tutsi, were killed by the third week of May. Apart from a few AK-47 rifles and grenades held by the elite, the predominant killing instruments were those of the hand-machetes or slashing knives, common agricultural tools called panga. The use of these instruments entailed that the executioners face their victims directly, see the blood run from their wounds, watch them die ... and then slash at another living body, again and again and again. The immediate question is why did it happen? How did we get to the point where the intended genocide of the Tutsi population of Rwanda became both thinkable and attempted? A thousand questions follow, some that bear also upon an understanding of the other case to be discussed: the break-up of Yugoslavia and the NATO air-war over Kosovo. One question that permeates this essay concerns the abstracted communities of identity-the 'nation' as a community of strangers, and even the modern 'tribe' as analogously abstracted when it too has become a post-kin-related community. How could such abstracted associations generate such powerful embodied personal and social identities as nationalism and tribalism? How do those often-positive identifications intensify to the point that a person is willing to kill a known 'other' for that identification? How, if at all, is globalism relevant to that intensification? More specifically in the cases of Rwanda or Bosnia and Kosovo, what impels people to kill other persons with whom, at the level of face-to-face interaction they have been living in an erstwhile fragile and ritualised amity? In the 
language of the present argument, they entail understanding the relationship between the embodied level of face-to-face relations and layers of more abstract forms of social life, extensions of integration conducted across time and space by institutional and disembodied means. It is important to note that in the pre-colonial period there was no evidence of systematic violence between the Hutu and Tutsi as such. Genocide, I suggest, is a modern phenomenon. When the Western media described the genocide as 'tribalism gone mad' they were completely blind to the complexity of the event.

The genocide was clearly underway by the evening of 7 April with the Presidential Guards beginning to work through the death lists of priority targets in the capital, and it quickly spread through the bureaucracy of the (French-trained) Interahamwe and Impuzamugambi militias and out to the countryside. The cold language of 'priority targets', 'bureaucracy' and is intentionally used here, for there is strong circumstantial evidence that the killing began that way-as a modern, institutionalised and premeditated operation of intentional genocide against the Tutsi and their sympathisers. The killing-machine, the Interahamwe, meaning 'those who work together', may have been haphazard but it was also a state-run volunteer service linked to involvement in a series of earlier massacres. While the carefully targeted killings quickly broadened into mayhem, a layer of institutional efficiency (and 'indifference' to the emotional consequences) remained behind the scenes. Gérard Prunier records that garbage trucks were used in Kigali to help dispose of the dead. To prevent epidemics, some 60,000 bodies were removed from the capital for burial. In short, the genocide was both a modern incident requiring instrumental planning and a neo-traditional fugue grounded in embedded differences. It was both an orchestrated single event conducted at a 'distance' by institutionally framed action and, once the slaughter had been initiated, a sporadic series of events spurred on by embodied face-toface confrontation.

Understanding what happened in Rwanda in 1994 entails looking at much more than the empirical particulars of the event itself. Each of the individual acts of murder in Rwanda in 1994 had its own specificity. For some it was intended as a means of getting rid of the evil Tutsi bodies that beset the 
land. For others it was under duress as a frightened public act attempting $b$ show overt commitment to the Hutu cause. For yet others it was, as one of the 'innocent murderers' (Jean-Pierre Chrétien's expression), putting one's spouse or child out of her misery on the command of a terror squad. However varied the individual's motivations may have been, behind these diverse instances lie more general patterns. The first dimension of patterned change involves the colonial polity and the way in which traditional processes of communal identity were simultaneously institutionalised as modern and legitimised as traditional or customary. In other words, the very nature of tribal difference was reconstituted as part of the global extension of colonialism to Africa in the late-nineteenth, early twentieth centuries. Globalism was thus at the heart of the formation of what, as an intentional oxymoron, we can call 'modern tribes'.

Although in relative terms nineteenth-century Rwanda was linguistically and culturally homogenous-and this makes the explanation harder-it was nevertheless divided into three main 'tribal' groupings: the majority Hutu, the Tutsi (officially, a minority of nine per cent of the total population before the massacre), and tiny group called the Tua. Understanding the relevance of this apparently unremarkable constitution of identity for the events of 1994, involves understanding how the nature of cultural division was hardened, and thus fundamentally changed by colonial edict long before that year. The precolonial polity, or at least one layer of it, was from the end of the eighteenth century a highly centralised kingdom based upon the semisacredness of its leaders-as far as we know, all pastoralists (Mamdani 1996, Maquet 1961: 124-8, 148-52). Only in the nineteenth century through the force of the globalising intruders, and as the identities of pastoralist and Tutsi became synonymous, did this become a double domination: pastoral aristocracy over agriculturalists and Tutsi over Hutu (and Tua). However, even then a process called kwihutura qualified the boundary between Tutsi and Hutu. It allowed the possibility, through accrual of pastoral wealth, of leaving behind Hutuness and becoming a Tutsi. Under German and then Belgian rule, Tutsi identity, associated with traditional power, and Hutu identity, associated with subjection, were separated by a strict caste-like division. Identity cards were issued and the Belgian colonisers used the traditional structure of chiefdom 
as the apparatus of (brutal) mediated administration. As Mahmood Mamdani brilliantly argues the colonial state depended on this meshing of the modern and traditional: "these powers were justified as "customary", and "custom" was proclaimed by the very authority sanctioned by the colonial power as "customary". This tautology was crystallized in the legal institu 12). ${ }^{18}$ The European power thus ruled through the Tutsi, now a modern tribecaste-class $^{19}$ who at the same time looked to embodied expressions of their 'essential' difference: greater height, longer noses and so on and thus at one level continued to treat themselves as tribes in the old way. ${ }^{20}$ As I began to argue earlier, the fixing of tribal identity involved globalising modernisation, as both sides, colonial and native, called for different reasons upon the subjectivity of customary continuity.

The second related point of explanation is simple but important. With independence from the Belgians in 1962 and formal power-sharing, the hierarchy of power was reversed by the weight of numbers. However, the colonial cultural heritage carried through, with the Hutu still feeling that oppressive weight of history. This resentment was confirmed by an invasion by 200 or 300 Tutsi refugees from Burundi. It was called the 'invasion of the cockroaches'. Politically driven killings of targeted Tutsi followed, with global bodies such as the United Nations reporting between 1,000 and 14,000 deaths. Thus, as the newly independent polity attempted to achieve what the development theorists of the time called 'nation-building', a run of return pogroms began. In 1988, a Hutu uprising in the north of neighbouring Burundi was followed by mass killings of Hutu; and, in 1990, Tutsi militia from Uganda

18 See also Louis (1963: part 2).

19 See LeMarchand (1970) on the complications of using the terminology of caste and class in relation to the Tutsi.

20 Despite these putative embodied differences, witnesses after the 1994 massacres talked of the executioners often demanding identity cards to determine if they were killing the right people. 
invaded as the Rwandan Patriotic Front (RPF). ${ }^{21}$ From this bloody history, some tentative conclusions can be drawn. The months of April and May 1994 were horrific, but 1994 was 'only' the most horrific episode of the many such episodes of violence that arose in the context of globally and locally produced deep uncertainty about the identity of the 'other' Rwandans. The new violence, in part, was based on a process of ideologically and administratively fixing that identity in an unsustainable modern hierarchy of power based on customary tribalism. This is an example of the overlaying of levels of ontological formation: modernism and tribalism.

Why was the fixing unsustainable? Why, rather than providing for cultural security as it might have under the ritualised conditions of traditional society, did it set up a history of ressentiment? This leads us to a further dimension of patterned change. Parallel but counter-developments, such as the changing nature of power in a 'democratic' and militarised postcolonial world, rendered that 'fixing' as increasingly fragile and crumbly. The backdrop to the 'reversal' of the hierarchy with formal independence in 1962 included for example more than a decade of UN decolonisation missions to take apart the fixity of Tutsi dominance. Other modern and globally carried counter-processes to the fixing of identity include the role of schoolbased modern education and the development of a monetary exchange system. These loosened the taken-forgranted certainty of traditional-then-colonial forms of identity without establishing anything workably solid in its place. Thus we have two kinds of tensions. First, there are tensions between the intersecting ontological formations-tribal, traditional and modern. Moreover there are tensions within modernism itself: tensions between sensitivity and indifference to difference;

21 The RPF, which again reversed the power hierarchy and returned the Tutsi to government in the wake of the 1994 genocide, had been formed in 1987 in Uganda. The unevenness of the process and how it spread beyond the borders of one nation-state is indicated by the fact that the RPF leader, Paul Kagame, had up until the early 1980s considered himself Ugandan. To carry the story forward: in August 1998, Tutsi-led rebels backed by Rwanda, claimed control of two-thirds of the Democratic Republic of the Congo. Angolan, Namibian and Zimbabwean troops were sent in to support President Kabila. The European nations, including former colonial power Belgium, organised a foreign evacuation. In Rwanda there are still rumoured to be Hutu rebel movements in the jungle. 
and tensions between the fixing of identity around reconstituted older forms and processes of its undermining, both incremental and revolutionary. Second, there are tensions between localism and globalism-in this case globalism expressed as imperial expansion and administrative extension.

\section{WAR OVERBOSNIA AND KOSOVO: FROM MODERN NATIONALISM TO DISEMBODIED VIOLENCE}

Just as in pre-colonial Rwanda where there is no evidence of systematic violence between the Hutu and Tutsi as such, in pre-war Bosnia, peoples of different narod and religion lived side by side in relative peace. At least at the level of village life, Catholic Croats, Orthodox Serbs and Bosnian Muslims, later named as the three markers of ethnic cleavage in the Bosnian war, lived together in carefully negotiated criss-crossing civic identity. As Tone Bringa (1995) describes, while the kinship networks and rituals of intimacy and religion remained separate, as did the architecture and culture of the household, the social and moral geography of the village provided points of interaction, even social integration for the different groups. The war changed all of this from above, although some patterns of interchange continued. For example, large numbers of Serbs worked underground to support those who were singled out for ethnic cleansing. In Kos ovo, the situation was similar with the driving force for systematic violence coming from the political leaders and institutionalised military responses as they incited local concerns. Though fuelled by a decade of tension, the first overt grassroots moves towards violence came as late as the mid-1990s. Just before Christmas 1997 in the village of Llaushe, armed members of the newly formed Kosovo Liberation Army appeared for the first time to confront Albanians at a funeral. It closed a circle of determinations. The thousands of Albanians had gathered to mourn the death of a school teacher killed by Serb police. Without wanting to suggest that face-to-face community is free of violence, it is galling to read the opposite-namely that it was the subjectivities of face-to-face community and its primordial memories of past grievances that underlay the war. The depictions in newspapers such as the New York Times were bad enough, but 
there were also academic writings attributing the causes of war to tribal divisions-primordial cleavages supposedly restrained by Tito's Yugoslavia, now bursting forth as ethnic nationalism. Trond Gilbert, for example, writes that the beginning of nationalism in the Balkans was, in reality, a form of

22 His writing is different only in tone and detail from newspaper articles such as, 'Old tribal rivalries in Eastern Europe pose threat New York Times 13 October 1991). ${ }^{23}$ His argument combines all the worst problems of such attributions, though nicely synthesised in an apparently subtle scholarly analysis. The argument is based on the usual ethnocentric claim about the differences between Western and Eastern nationalism, the first, civic and accepting of global diversity, the second, ethnic, culturally homogenising and bad. 'Cultural nations', he says wrongly, 'lend themselves to tribalism, whereas political nations do not' (Gilbert 1998: 67). ${ }^{24}$ From there we follow the well-trodden path to the necessity of Western intervention: 'Tribes in possession of modern weaponry and destructive techniques can only be constrained by counterforce' (Gilbert 1998: 76). ${ }^{25}$ This pronouncement tells us more about the dominant political culture of the West during the Bosnian-Kosovan interventions than it does about the complexites of life on the ground in the Balkans. It is to this side of the story -the dominant political culture of the United Kingdom and the United States - that I want to direct the focus of this study, just trying to open up the

22 Michael Keating (1998) writing in the same volume rightly distances himself fom the moral assumptions of the civic-ethnic nationalism sentiments, but then falls for the parallel moral dichotomy. The new nationalisms, he writes, 'may be benevolent, democratic and progressive [i.e., good], or represent a retreat into tribalism [i.e., bad]' (1998: 35).

23 On representations of the war, both academic and popular, see Campbell (1998: 53-81).

24 This claim forgets, for example, the self-proclamations of Celtic tribal roots by the southern leagues of the United States, that is in the 'pre-eminent Western civic nation' upon this planet. See Sebesta (2000).

25 While I basically disagree with the analysis, this is not say that tribalism is not crucial to understanding Balkan history or that it is irrelevant to its present. In the present there can be said to be elements of tribalism to the extent that the organised gangs, that emerged with the collapse of communism, became an encompassing way of embodied life for some people. On the past and its incorporation into the traditional state and society see Durham (1928). 
problems of understanding rather than developing any conclusions at this stage.

What was the cultural-political context that normalised the necessity of NATO's massive intervention in Kosovo? What does it tell us about the changing nature of nationalism that when Bill Clinton and Tony Blair talked about the necessity of the 'humanitarian bombing' of Kosovo it was done in the name of globalism rather than national interest? What does it mean that these political leaders were so concerned that the war should remain undeclared and strategically mediated by technological military means? What is the basis of the relatively new political obsession about not putting troops on the ground, and having no body bags return home to mark the tragedy of the conflict? The simple answer to these questions is that NATO did not want to be there in Kosovo. They were forced to by a series of contingent blunders and misunderstandings including a politics of ultimatum against Milosovic that was never going to work without either carpet bombing Kosovo and Serbia or putting massive numbers of troops into the region. Against the backdrop of inaction during the 1994 Rwandan massacre and the 1992-96 episodes of Bosnian Muslims being ethnically cleansed—both of which gradually became media-broadcast sources of Western guilt-Clinton and Blair felt that they had to find a 'third way'. This sensibility and structure of international considerations from outside Yugoslavia, and a modern revival of neotraditionalism from inside that federation, ended in a postmodern air-war of vast destruction from above and a ghastly modern ground-war of ethnic cleansing from below. That is the simple answer, not wrong, but as with the Rwandan situation such an explanation takes far too much for granted. It would take masses of background work in order to develop a more satisfactory account. All that I can hope to do here is critically examine aspects of the postnationalist culture in the West that made the abstract violence of dropping bombs from a great height appear defensible as a humanitarian intervention.

A recent tome, Blood sacrifice and the nation: Totem rituals and the American flag published by one of the world's most respected university presses, provides a fantastic example of a theory that has a snowball's 
chance in hell of explaining this phenomenon of postnational abstract violence (Marvin and Ingle 1999). The book's thesis, that the nation is a tribe founded on a civic religion that demands the blood sacrifice of its children, is made all the more dramatic by taking as its example the United States, a highly differentiated nation without a singular ethnic genealogy let alone tribalnational roots. Let the authors first set out their approach in their own words:

What binds the nation together? ... This book argues that violent blood sacrifice makes enduring groups cohere, even though such a claim challenges our most deeply held notions of civilized behavior.

The sacrificial system that binds American citizens has a sacred flag at its centre. Patriotic rituals revere it as the embodiment of a bloodthirsty totem god who organizes killing energy. This totem god is the foundation of the mythic, religiously constructed American identity. Our notion of the totem comes from Durkheim, for whom it was the emblem of the group's agreement to be a group ... We intend to show totem dynamics vigorously at work in the contemporary United States. We lay out the practices and beliefs that furnish the system without which the nation is in danger of dissolution. Their focus is the magical and primitive use of the flag, the totem object of American civil religion (Marvin and Ingle 1999: 1).

At first I thought this writing was merely the metaphoric excess of the introductory page, rhetoric used to draw in the reader before settling down to the serious analysis. However, for all the wealth of empirical description, the book never gets beyond detailed description and methodological mire. The most important insight for our purposes is that the pre-eminent civic nation, the USA, still uses the rhetoric and subjectivity of blood sacrifice. This goes against the classical modernist argument. However, Blood sacrifice and the nation leaves us with too many questions. How can such a differentiated nation, a nation that does not believe that embodied genealogical kinship is the means of its integration, be considered a tribe? Through its totem system, answer Marvin and Ingle - the kinship form is exogamy. There is no post modern irony here, only bad theory. Exogamy, they say, actually organises popular elections and reconciles potentially violent political-clan differences:

Two major clan groups bearing animal identities are descended from the flag, the tribal ancestor, for whom the totem eagle is occasionally substituted.

During seasonal festivals called elections, representatives of the elephant 
and donkey clans form an exogenous mating pair that produces a reincarnated savior king, an embodied totem president who bears a sacrificial charge ... The cross-fertilized membership of the two great non-exclusive electoral clans deflects potentially murderous struggle. It reorganizes the identities of contending groups by focusing away from irreconcilable differences associated with exclusive affiliation by blood and subordinating these differences to blood ties of totem sacrifice (Marvin and Ingle 1999: 223). 26

The tensions in the method abound and show themselves in obvious ways. America is both one large differentiated tribe, and a nation of tribes in the plural. The totemic fathers of the nation are those established by sacrifice in war, but Marvin's list singles out as 'the most significant totem avatars for living Americans' the venerated war heroes (not), Franklin D. Roosevelt and John F. Kennedy. Roosevelt did not enter World War II until forced to in December 1941; and Kennedy presided over the Bay of Pigs fiasco, the Cuban missile backdown and had the 16,000 troops hidden in Vietnam under the guise of being advisors. The evidence is ambiguous as it is for their description of the flag. For Marvin and Ingle, the flag is simultaneously the god of nationalism, the totem emblem, a body, a representative of the violently sacrificed body, and the 'baby' that came from Betsy Ross's body. It is both an artefact based on oral not textual culture and the intimate subject of poems, novels, advertisements, newspaper articles and television programs. It is the totem 'whose mission it is to organise death', the object that must not be used for commercial purposes, and it is also the motif on everything commercial from table linen to condoms. It is the male, transcendent totem that is taboo to touch (even though the Old Glory Condom Company ran advertisements around the slogan 'never flown at halfmast) and the female, popular totem that expresses itself in the 'messy, rutting shoving, know the answers to questions about baseball (Marvin and Ingle 1999: 23). ${ }^{27}$

Such analyses cannot explain the kind of nationalism that fears the return of the body bags from hot spots of conflict and abhors the death of its own

26 This is the subject of their chapter 9.

27 Compare, for example, pages 22 and 192; 19 and 22; 29, 25, 42, 43 and 11; 423 and numerous discussions of the flag's textual representations; 20 and 29; 32 , 54 and 215. 
soldiers. When late-modern states such as the USA present themselves as postnational, acting violently in the interests of global peace, it suggests that the sensibility of postnationalism needs to be understood in quite different terms. ${ }^{28}$ On the other hand, it is salutary or the direct advocates of postnationalism such as Appadurai, and less explicit postnationalists such as Anthony Appiah29 and Richard Rorty, ${ }^{30}$ to remember that it is that very nation-state that they present as a post-melting-pot, postnational experimentthe USA - that has over the last decade been involved in more systematic violence projected outside its borders than any state since Hitler's Third Reich. In the war against Iraq, filmed as a war without significant casualties, thousands of anonymous soldiers were drowned in sand as NATO tanks with bulldozer-fronted shields filled in Iraqi-held trenches. In the 1999 war against Serbia, the aerial bombing, intended to limit the ethnic cleansing of Kosovo, firstly exacerbated the possibility for the Yugoslav militia effecting the mass exodus of hundreds of thousands of Albanian Kosovars, and secondly stabilised the situation around a reverse ethnic homogeneity. Twelve-hundred civilians were killed by the bombs, the very people supposedly being protected. Although not intended as a totalising denunciation, these facts sit uncomfortably alongside Appadurai's extolling of the 'sheer cultural vitality of this free-trade zone' called America. True, it is possible to have a pluralistic

28 Although recontextualised, the next couple of pages are based closely on James (1999/2000).

29 Appiah's argument for 'rooted cosmpolitanism' is based on the defence of the liberal freedom to have elective affinities. It is, in his words, a 'distinctively American tadition'. He writes: 'Those of us who are American not by birth but by election, ... love this country precisely for that freedom of self-invention ...' (1998: 106).

30 See Rorty (1998) for his postmodern patriotism, a kind of postnationalism that at once allows him to romanticise and be utterly critical of the politics of his nationstate, America. As Michael Billig notes (1995: 170): 'Rorty directly associates himself with Dewey's vision of America: "I see America pretty much as Whitman and Dewey did, as opening up a prospect of illimitable democratic vistas"' Billig continues (1995: 172): 'In such writings it is possible to identify a tone suited to the new Pax Americana. The philosophy distances itself from the rhetoric of the Cold War... [At the same tme, the] American way-the way of non-ideological pragmatism -is recommended for all'. I'm afraid, for all Rorty's ironical distance from that thing called 'America', I agree with Billig. 
cultural vitality that celebrates dfference at the time that the world is made safe for a homogenising system of economic exchange. True, Appadurai does ask for call for the further pursuit of liberty and cultural difference through legal protections. However, the full force of his call to America takes the form of going with the flow of postmodern global capitalism:

For the United States, to play a major role in the cultural politics of a postnational world has very complex domestic entailments ... It may mean a painful break from a fundamentally Fordist, manufacture-centred conception of the American economy, as we learn to be global information brokers, service providers, style doctors. It may mean embracing as part of our livelihood what we have so far confined to the world of Broadway, Hollywood, and Disneyland: the import of experiments, the production of fantasies, the export of styles, the hammering out of pluralities. It may mean distinguishing our attachment to America from our willingness to die for the United States ... America may yet construct another narrative of enduring existence, as narrative about the uses of loyalty after the end of the nation-state (Appadurai 1996: 175-6).

While lots of good things have come out of America, this argument is bizarre. For too long American cultural exporters have been constructing narratives for others. Three glaring problems with the passage deserve critical noting. First, as many other writers have argued, it is misguided to think that the movement from Fordism to what David Harvey (1989) calls 'flexible accumulation', 31 brings about a brave new world of equality-indifference. One has only to look to the plight of the diaspora Chicano community of the eastern seaboard to see how immigrant cultures can be super-exploited in the information age. Second, although separating attachment to America (presumably good) from willingness to die for it (supposedly bad) may be laudable depending upon what it means in practice, it no longer takes us very far into developing a positive form of postnationalism. In the presentation of the technologically sophisticated wars conducted by US-led NATO forces over Iraq and Kosovo, much was made of the fact that very few of 'our boys' died. From a position of technological military strength, willingness to kill from a distance has largely surpassed the old-fashioned willingness to die for one's nation as a basis of the call to arms.

31 See also Castells (1996). 
The third problem with the passage cited above concerns the embracing of Hollywood and the style-doctors. For a long time now Hollywood has joined in the postmodern game of presenting America as if it were already postnational and therefore able to stand in for the world at moments of crisis. Postnationalist films such as Independence Day (1996) and Armageddon (1997) have largely replaced the Cold War nationalism which had Rocky Bilboa wearing stars-and-stripes boxing shorts and stepping into the ring to defeat Ivan Drago, the best that Soviet science could create. ${ }^{32}$ Hollywood's America now only fights wars over the thin red line of national territory as reruns of old conflicts. With some notable exceptions such as Wag the Dog (1997), the American war-machine is uncritically portrayed as projected globally rather than nationally self-serving in orientation. ${ }^{33}$ However, if you read between the lines, the thrust of the set speeches in these films still assume that the United States-as on the one hand postnational representative of a set of universalistic values and on the other as exemplary opentextured nation-state - sits at the helm of world politics. It is the kind of postnationalism that makes 'humanitarian' interventions into Iraq and Kosovo as easily thinkable as leaving to others the peacekeeping mission into East Timor. In Independence Day, Bill Pullman, President of the United States, speaks of the fourth of July becoming the rallying point for all mankind:

Good morning. In less than an hour, aircraft from here will join with others from around the world. And you will be launching the largest aerial battle in the history of mankind. 'Mankind' - that word should have new meaning for all of us. We can't be consumed by petty differences any more. We will be united in our common interest. Perhaps it's faith. Today is the fourth of July, and you will once more fight for our freedom. Not from tyranny, oppression or persecution, but from alienation. We're fighting for our right to live, to exist. And should we win the day, the fourth of July will no longer be known as an American holiday, but as the day when the whole world declared in one voice: 'we will not go quietly into the night, we will not vanish without a fight,

32 Rocky IV, 1985, a United Artists film, written and directed by Sylvester Stallone.

33 Criticism is reserved for those unethical individuals perverting the system who fail to live up to the abstract ideals of life, liberty and the American way. Usually these individuals and their cronies are exposed by the Harrison Ford or Denzel Washington hero. 
we are going to survive'. Today we celebrate our independence day!

(emphasis added).

It is striking how comfortably Hollywood translates fighting for trans national peace back into the heritage of one nation: pax Americana. The fourth of July is not just another American holiday. It signifies the formation of the modern American nation. When we get to the last line, 'Today we celebrate our independence day', the ambiguous appellation 'our' has linked modern nationalism and postmodern cosmopolitanism in a comfortable pastiche that challenges nothing.

Hollywood even makes it sound as if it is hard work. In The American President the President of the United States, Michael Douglas, talks about the need to acknowledge the struggle:

America isn't easy. America is advanced citizenship. You've got to want it bad, 'cause it's going to put up a fight. It's going to say 'You want free speech? Let's see you acknowledge a man who makes your blood boil, who's standing centre-stage and advocating at the top of his lungs that which you would spend a life-time opposing at the top of yours. You want to claim this land as the land of the free? Then the symbol of your country cannot just be the flag. The symbol has also to be one of its citizens exercising his right to burn that flag in protest.'

In one very particular way, the postnational nation is hard work. ${ }^{34}$ It is hard work reconciling the tensions. This point provides a good way of concluding the essay. Despite continuities the postnational nation is very different from that of the modern imperial nations such as late nineteenth-century England, Germany or even the frontier-expanding United States. Today's postnations have to carry their pasts with them while simultaneously forgetting/remembering the oppressive practices of that past. They have to commemorate their origins and histories while distancing themselves from

34 The term 'postnational nation', may sound oxymoronic, but it is explicable in terms of a levels argument that treats modernism (which frames the experience of bounded national community) and postmodernism (which frames the experience of heterogeneous multicultural society) as contradictory formations overlaying each other and coexisting in the same 'world time'. 
previous acts of oppressive violence at the heart of those histories. 35 Rudyard Koling's England gloriously projected itself as engaged in the 'white man's burden' to spread its civilisation and power, territorially and globally. The impact of the imperial nations on their colonies was profound and we are still living with its consequences. Rwanda is but one example. However, Blair's England is less sure. In this new problem of remembering/ forgetting the new global nations ${ }^{36}$ can partially comfort themselves with the new 'reality' that they are no longer interested in extending global erritoriality or painting the map the latest version of 'empire red'. The trouble is that they strangely find themselves continually beckoned into wars that ostensibly they do not want to fight. The denizens of such countries, including those of Tony Blair's new England and Bill Clinton's USA, thus have many competing and contradictory issues to consider: modern ideas of old-fashioned national interest; late-modern concerns about universalistic human rights; and postmodern aversions to the 'ultimate sacrifice' such as dying for a cause, or watching the body-bags return from a place of foreign military intervention. They are caught up in postnational hopes, which under pressure quickly slip back into misremembered national ideals. More dangerously they are caught in the delusion that most of the violence in the world comes from the contemporary reversions to primordial tribalisms rather than being bound up with the very processes of abstract globalism that they so heartily espouse.

If the unmasking of the contradictions of postnational globalism is at the centre of the political conclusion being drawn here, the need for a new approach to theory and method is crucial to the conceptual conclusion. Understanding the relationship between globalism, nationalism and tribalism will entail developing an approach that takes seriously both their concurrent and intersecting reality, and the way in which they are set within a world of deep ontological contradictions. It is simply unhelpful to say that under conditions of contemporary globalisation that primordial tribalism is being revived from near extinction or that nationalism is dying the death of anachronism. An

35 See Anderson (1991: chapter 11) on the modern issue of remembering and forgetting. Here I am stretching the concept in a way that Anderson perhaps did not intend.

36 The term 'global nation' comes from Wiseman's (1998) book of the same name. 
alternative approach can be initiated through two relatively simple steps. The first step involves setting up a method that analyses the intersection of coterminous formations-tribalism, traditionalism, modernism and postmodernismand does so without collapsing them into each other. The second step involves analytically working across different levels of integration from embodied face-to-face to the disembodied abstracted relations between people. This takes us back to the political point: uncritically advocating postnationalism, at least when it takes the form of privileging the mobile possibilities of highly abstracted and globalising relations, is to also find oneself defending new forms of power and cultural legitimation.

\section{REFERENCES}

Albrow, Martin, 1996. The global age, Polity Press, Cambridge.

Anderson, Benedict, 1991. Imagined communities, $2^{\text {nd }}$ edition, Verso, London.

Appadurai, Arjun, 1996. Modernity at large: Cultural dimensions of globalization, University of Minnesota Press, Minneapolis.

Appiah, Kwame Anthony, 1998. 'Cosmopolitan patriots', in Pheng Cheah and Bruce Robbins, eds, Cosmopolitics: Thinking and feeling beyond the nation, University of Minnesota Press, Minneapolis.

Billig, Michael, 1995. Banal nationalism, Sage Publications, London.

Bringa, Tone, 1995. Being Muslim the Bosnian way: Identity and community in a central Bosnian village, Princeton University Press, Princeton.

Campbell, David, 1998. National deconstruction: Violence, identity and justice in Bosnia, University of Minnesota Press, Minneapolis.

Castells, Manuel, 1996. The information age: Economy, society and culture: Vol. 1, The rise of the network society, Blackwell Publishers, Cambridge, Mass.

Cheah, Pheng, 1998. 'The cosmopolitical Today', in Pheng Cheah and Bruce Robbins, eds, Cosmopolitics: Thinking and feeling beyond the nation, University of Minnesota Press, Minneapolis.

Dodgshon, Robert A., 1998. From chiefs to landlords: Social and economic change in the western highlands and islands, c. 1493-1820, Edinburgh University Press, Edinburgh.

Durham, Mary Edith, 1928. Some tribal origins, law and customs of the Balkans, George Allen \& Unwin, London.

Gibson, William, 1993. Virtual light, Bantam Books, New York.

Giddens, Anthony, 1990. The consequences of modernity, Polity Press, Cambridge. 
Guéhenno, Jean-Marie, 1995. The end of the nation-state, University of Minnesota Press, Minneapolis.

Gilbert, Trond, 1998. 'Ethnic conflict in the Balkans: Comparing ex-Yugoslavia, Romania and Albania', in Kenneth Christie, ed., Ethnic conflict, tribal politics: A global perspective, Curzon Press, Richmond.

Harvey, David, 1989. The condition of postmodernity: An enquiry into the origins of cultural change, Basil Blackwell, Oxford.

Herzfeld, Michael, 1992. The social production of indifference: Exploring the symbolic roots of Western bureaucracy, University of Chicago Press, Chicago.

James, Paul, 999/2000. 'Beyond a postnationalist imaginary: Grounding an alternative ethic', Arena Journal new series no. 14: 53-74.

Johnston, Alexander, 1998. 'Ethnic conflict in post Cold War Africa: Four case studies', in Kenneth Christie, ed., Ethnic conflict, tribal politics: A global perspective, Curzon Press, Richmond.

Keating, Michael, 1998. 'Minority nationalism or tribal sentiments', in Kenneth Christie, ed., Ethnic conflict, tribal politics: A global perspective, Curzon Press, Richmond.

LeMarchand, René, 1970. Rwanda and Burundi, Pall Mall Press, London.

Louis, William Roger, 1963. Ruanda-Urundi: 1884-1914, Clarendon Press, Oxford.

Mamdani, Mahmood, 1996. 'From conquest to consent as the basis of state formation: Reflections on Rwanda', New Left Review216: 3-36.

Maquet, Jacques J., 1961. The premise of inequality in Ruanda, Oxford University Press, London.

Marvin, Carolyn, and David W. Ingle, 1999. Blood sacrifice and the nation: Totem rituals and the American flag, Cambridge University Press, Cambridge.

Ohmae, Kenichi, 1996. The end of the nation state: The rise of regional economies, Harper Collins, London.

Prunier, Gérard, 1997. The Rwandan crisis: History of a genocide, Columbia University Press, New York.

Robbins, Bruce, 1998. 'Actually existing cosmopolitanism', in Pheng Cheah and Bruce Robbins, eds, Cosmopolitics: Thinking and feeling beyond the nation, University of Minnesota Press, Minneapolis.

Robertson, Roland, 1992. Globalization: Social theory and global culture, Sage, London.

Robertson, Roland, 1995. 'Glocalization: Time-space and homogeneityheterogeneity', in Mike Featherstone, Scott Lash and Roland Robertson, eds, Global modernities, Sage, London.

Rorty, Richard, 1998. Achieving our country: Leftist thought in twentiethcentury America, Harvard University Press, Cambridge.

Sebesta, Edward H., 2000. 'The confederate memorial tartan', in Scottish Affairs 31: 55-84. 
Relating Global Tensions

Silberman, Steve, 1999. 'Just say Nokia', Wired Magazine 7(9), <http:/hww.wired.com/ wired/archive/7.09/nokia.htmb.

Stephenson, Neal, 1992. Snow crash, Penguin, Harmondsworth.

Wiseman, John, 1998. Global nation?,Cambridge University Press, Cambridge.

Wolf, Eric R., 1982. Europe and the people without history, University of California Press, Berkeley. 


\section{Department of International Relations}

\section{PUBLICATIONS}

\section{as at 1 July 2001}

Send all orders to:

RSPAS Publishing (PICS)

Research School of Pacific and Asian Studies

The Australian National University

Canberra ACT 0200 Australia

Phone: +6126125 3269 Fax: +61 261259975

E-mail: jo.bushby@anu.edu.au

Web: http://rspas -bookshop.anu.edu.au

WORKING PAPERS

WP2001/1 Relating Global Tensions: Modern Tribalism and Postmodern Nationalism, by Paul James

WP2000/4 The English School in China: A Story of How Ideas Travel and are Transplanted, by Yongjin Zhang

WP2000/3 Death of Distance or Tyranny of Distance? The Internet, Deterritorialisation, and the Anti-Globalisation Movement in Australia, by Ann Capling and Kim Richard Nossal

WP2000/2 Globalisation and Security in East Asia, by Peter Van Ness

WP2000/1 Managing the US Base Issue in Okinawa: A Test for Japanese Democracy, by Aurelia George Mulgan

WP1999/5 Internationalisation: What Scholars Make of It?, by N. Hamilton-Hart

WP1999/4 The Asian Regional Response to its Economic Crisis and the Global Implications, by Stuart Harris

WP1999/3 ASEAN and the Southeast Asian 'Haze': Challenging the Prevailing Modes of Regional Engagement, by James Cotton

WP1999/2 Australia and Nuclear Arms Control as 'Good International Citizenship', by Marianne Hanson

WP1999/1 South Pacific Security and Global Change: The New Agenda by Greg Fry

WP1998/3 The Rise of an Environmental Superpower? Evaluating Japanese Environmental Aid to Southeast Asia, by Peter Dauvergne

WP1998/2 Environmental Insecurity, Forest Management, and State Responses in Southeast Asia, by Peter Dauvergne

WP1998/1 The ASEAN Regional Forum. A Model for Cooperative Security in the Middle East? by Michael Leifer

WP1997/8 From Paternalism to Partnership: Australia's Relations with ASEAN, by John Ravenhill

WP1997/7 Globalisation and deforestation in the Asia-Pacific, by Peter Dauvergne

WP1997/6 Corporate Power in the Forests of the Solomon Islands,

by Peter Dauvergne 
WP1997/5 From Island Factory to Asian Centre: Democracy and Deregulation in Taiwan, by Gregory W. Noble

WP1997/4 The Foreign Policy of the Hawke-Keating Governments: An Interim Review, by James L. Richardson

WP1997/3 Hedley Bull and Interna tional Security, by Samuel M. Makinda

WP1997/2 Island Disputes in Northeast Asia, by Andrew Mack

WP1997/1 Nuclear 'Breakout': Risks and Possible Responses, by Andrew Mack

WP1996/10n/a

WP1996/9 The Rajin-Sonbong Free Trade Zone Experiment: North Korea in Pursuit of New International Linkages, by James Cotton

WP1996/8 The Declining Probability or War Thesis: How Relevant for the Asia-Pacific?, by James L. Richardson

WP1996/7 The China-Japan Relationship and Asia-Pacific Regional Security, by Stuart Harris

WP1996/6 You Just Don't Understand: Troubled Engagements Between Feminists and IR Theorists, by J. Ann Tickner

WP1996/5 Framing the Islands: Knowledge and Power in Changing Australian Images of 'The South Pacific', by Greg Fry

WP1996/4 The Constructivist Turn: Critical Theory After the Cold War, by Chris Reus-Smit

WP1996/3 Why Democracies Don’t Fight Each Other: Democracy and Integration, by Harvey Starr

WP1996/2 The New Peacekeepers and the New Peacekeeping, by Trevor Findlay

WP1996/1 Ameliorating the Security Dilemma: Structural and Perceptual Approaches to Strategic Reform, by Andrew Butfoy

WP1995/10 Contending Liberalisms: Past and Present, by James L. Richardson

WP1995/9 Industry Policy in East Asia: A Literature Review, by Heather Smith

WP1995/8 Recasting Common Security, by Andy Butfoy

WP1995/7 Russian Policy Towards the 'Near Abroad': The Discourse of Hierarchy, by Wynne Russell

WP1995/6 Culture, Relativism and Democracy: Political Myths About 'Asia' and the by Stephanie Lawson

WP1995/5 The World Trade Organisation-Throwing the Baby Out With the Bath Water? by P.A. Gordon

WP1995/4 The Neo-Classical Ascendancy: The Australian Economic Policy Community and Northeast Asian Economic Growth, by Trevor Matthews and John Ravenhill

WP1995/3 In Search of a New Identity: Revival of Traditional Politics and Modernisation in Post-Kim II Sung North Korea, by Alexandre Y. Mansourov

WP1995/2 Implications of Taiwan-Chinese Relations for Australia, by Stuart Harris

WP1995/1 New Light on the Russo-Japanese Territorial Dispute, by Kimie Hara

WP1994/10 China's Public Order Crisis and Its Strategic Implications, by Greg Austin

WP1994/9 Nuclear Endgame on the Korean Peninsula, by Andrew Mack

WP1994/8 Human Rights and Cultural Specificity: The Case of Papua New Guinea, by Michael Jacobsen

WP1994/7 'Climbing Back onto the Map?': The South Pacific Forum and the New Development Orthodoxy, by Greg Fry

WP1994/6 The Asia-Pacific: Geopolitical Cauldron or Regional Community? by James L. Richardson 
WP1994/5 North Korea's Nuclear Program: the Options are Shrinking, by Andrew Mack

WP1994/4 Policy Networks and Economic Cooperation: Policy Coordination in the Asia-Pacific Region, by Stuart Harris

WP1994/3 Australia's Regional Security Environment, by Stuart Harris

WP1994/2 The Future of Asia-Pacific Security Studies in Australia, by Pauline Kerr and Andrew Mack

WP1994/1 Inter-Civilisation Conflict: A Critique of the Huntington Thesis, by Jacinta O'Hagan

WP1993/10 Nuclear-Free Zones in the 1990s, by Andrew Mack

WP1993/9 Aus tralian Security in the 1990s, by Andrew Mack

WP1993/8 Concepts of Security in the Post-Cold War, by Andrew Mack

WP1993/7 An American New World Order?, by James L. Richardson

WP1993/6 The Return of Practical Reason, by Hayward R. Alker, Jr.

WP1993/5 Gaddis' Lacuna: Foreign Policy Analysis and the End of the Cold War, by Valerie Hudson

WP1993/4 The Environment and Sustainable Development: An Australian Social Science Perspective, by Stuart Harris

WP1993/3 Environmental Regulation, Economic Growth and International Competitiveness, by Stuart Harris

WP1993/2 Strategic Trade Policy: The East Asian Experience, by Trevor Matthews and John Ravenhill

WP1993/1 The Practice of Common Security: China's Borders with Russia and India, by Gary Klintworth

WP1992/10 Arms Proliferation in the Asia-Pacific: Causes and Prospects for Control, by Andrew Mack

WP1992/9 Nuclear Dilemmas: Korean Security in the 1990s, by Andrew Mack

WP1992/8 The Case For a Nuclear Weapon-Free Zone in Northeast Asia, by Andrew Mack

WP1992/7 The Gulf War and Australian Political Culture, by James L. Richardson

WP1992/6 The Economic Aspects of Pacific Security, by Stuart Harris

WP1992/5 Moving Target-Korea's Nuclear Proliferation Potential, by Peter Hayes

WP1992/4 Federalism and Australian Foreign Policy, by Stuart Harris

WP1992/3 New Hierarchies in East Asia: The Post-Plaza Division of Labour, by Mitchell Bernard and John Ravenhill

WP1992/2 Questions About a Post-Cold War International Order, by J.L. Richardson

WP1992/1 After the Cold War and the Gulf War: Prospects for Security in the AsiaPacific, by Andrew Mack

WP1991/10The Korean Nuclear Issue, by Song Young Sun

WP1991/9 Implementing Foreign Policy: The Environmental Challenge, by Stuart Harris

WP1991/8 Australia and the South Pacific: From 'Strategic Denial' to 'Constructive , by Greg Fry

WP1991/7 'Civil Society’ and Nationalism in North Korea: Foundations for Political Change? by James Cotton

WP1991/6 The Drawbacks of the Detached View: Russia, the USSR and the Pacific, by Artem Rudnitskiy 


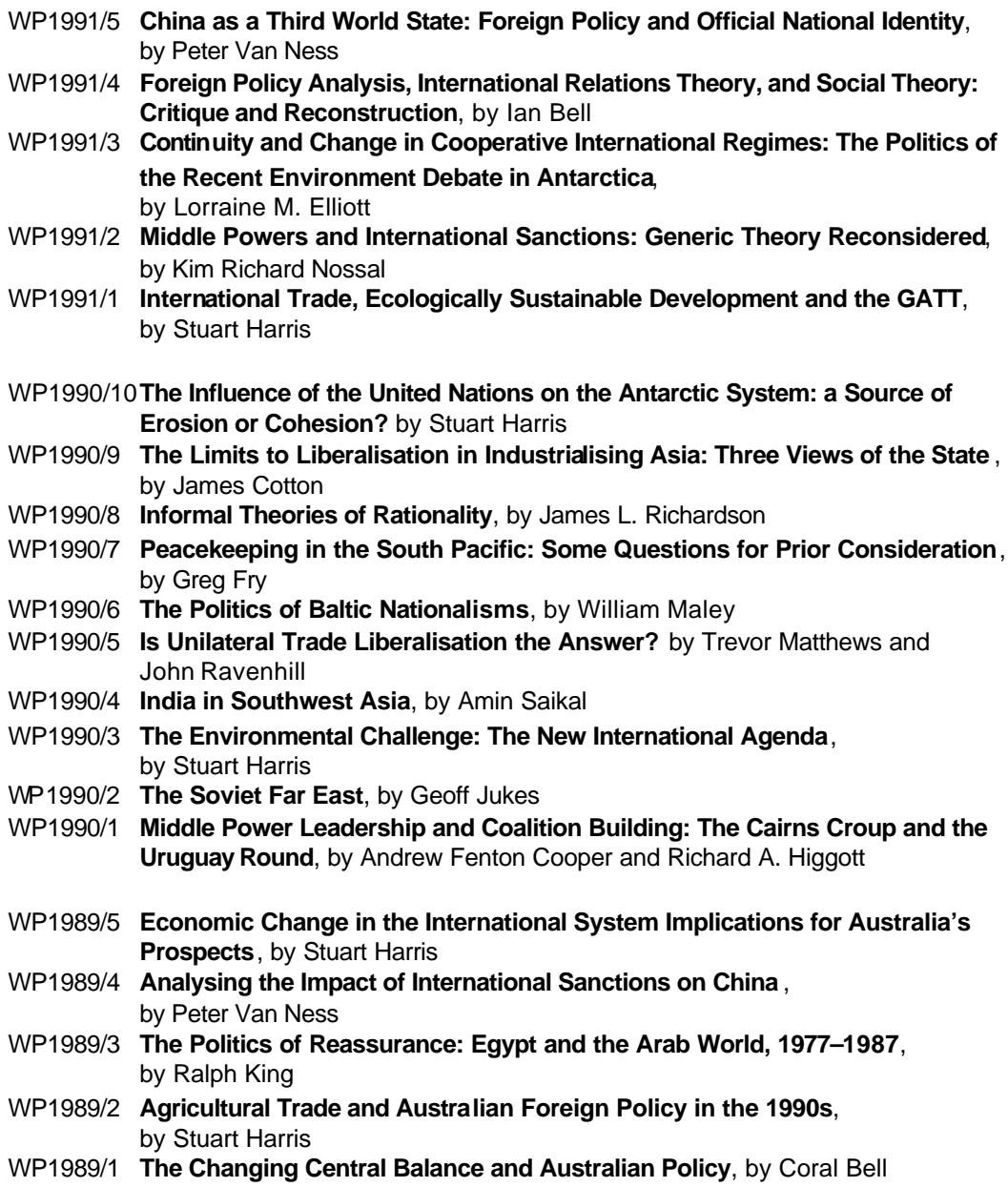

Price: All at the one price of $\$ A 5.00$. 
Studies In WorLd Affairs

Ethics and Foreign Policy, edited by Paul Keal

Korea Under Roh Tae-woo: Democratisation, Northern Policy, and

Inter-Korean Relations, edited by James Cotton

1. Asian-Pacific Security After the Cold War, edited by T.B. Millar and James Walter

2. The PostCold War Order: Diagnoses and Prognoses, edited by Richard Leaver and James L. Richardson

3. Dependent Ally: A Study in Australian Foreign Policy, 3rd ed., by Coral Bell

4. A Peaceful Ocean? Maritime Security in the Pacific in the Post-Cold War Era, edited by Andrew Mack

5. Asian Flashpoint: Security and the Korean Peninsula, edited by Andrew Mack

6. Taiwan in the Asia-Pacific in the 1990s, edited by Gary Klintworth

7. Pacific Cooperation: Building Economic and Security Regimes in the Asia-Pacific, edited by Andrew Mack and John Ravenhill

8. The Gulf War: Critical Perspectives, edited by Michael McKinley

9. Search for Security: The Political Economy of Australia's Postwar Foreign and Defence Policy, by David Lee

10. The New Agenda for Global Security, Cooperating for Peace and Beyond, edited by Stephanie Lawson

11. Presumptive Engagement: Australia's Asia Pacific Security Policy in the 1990s, by Desmond Ball and Pauline Kerr

12. Discourses of Danger and Dread Frontiers: Australian Defence and Security Thinking After the Cold War, edited by Graeme Cheeseman and Robert Bruce

13. Pacific Rim Development: Integration and Globalisation in the Asia-Pacific Economy, edited by Peter J. Rimmer

14. Evatt to Evans: The Labor Tradition in Australian Foreign Policy, edited by David Lee and Christopher Waters

15. Cambodia-From Red to Blue: Australia's Initiative for Peace, by Ken Berry

16. Asia-Pacific Security: The Economics-Politics Nexus, edited by Stuart Harris and Andrew Mack

17. China's Ocean Frontier: International Law, Military Force and National Development, by Greg Austin

18. Weak and Strong States in Asia-Pacific Societies, edited by Peter Dauvergne

19. Australian Outlook: a History of the Australian Institute of International Affairs, by J.D. Legge

20. Transforming Asian Socialism: China and Vietnam Compared by Anita Chan, Benedict J. Tria Kerkvliet, and Jonathan Unger 
Canberra Studies in World Affairs

CS21 Politics, Diplomacy and Islam: Four Case Studies, edited by Coral Bell

CS22 The Changing Pacific: Four Case Studies, edited by Coral Bell $\$ \$ 10.00$

CS23 New Directions in International Relations? Australian Perspectives, edited by Richard Higgott

CS24 Australia and the Multinationals: A Study of Power and Bargaining in the 1980s, by Neil Renwick

CS25 Refugees in the Modern World, edited by Amin Saikal

$\$ 10.00$

CS27 Northeast Asian Challenge: Debating the Garnaut Report, edited by J.L. Richardson

CS28 The ANZUS Documents, edited by Alan Burnett with Thomas-Durell Young and Christine Wilson

CS29 Human Rights in the Asia-Pacific Region edited by John Girling

CS30 International Relations: Global and Australian Perspectives on an Evolving Discipline, edited by Richard Higgott and J.L. Richardson

Australian Foreign Policy Papers

Australia's Alliance Options: Prospect and Retrospect in a

World of Change, by Coral Bell

Coping With Washington: Players, Conventions and Strategies,

by Davis Bobrow

$\$ 10.00$

The European Community in Context by John Groom

$\$ 15.00$

Australia's Human Rights Diplomacy, by lan Russell, Peter Van Ness and Beng-Huat Chua

$\$ 15.00$

Selling Mirages: The Politics of Arms Trading, by Graeme Cheeseman

$\$ 15.00$

The Search for Substance: Australia-India Relations into the

Nineties and Beyond by Sandy Gordon

Protecting the Antarctic Environment: Australia and the

Minerals Convention by Lorraine Elliott

Australia's Taiwan Policy 1942-1992, by Gary Klintworth

Australia and the New World Order: Evatt in San Francisco, 1945,

by W.J. Hudson

The Beijing Massacre: Australian Responses, by Kim Richard Nossal

The Pacific Patrol Boat Project: A Case Study of Australian

Defence Cooperation, by Anthony Bergin

A Select Bibliography of Australia's Foreign Relations, 19751992

compiled by Pauline Kerr, David Sullivan and Robin Ward 
Paul James

\title{
DEPARTMENT OF INTERNATIONAL RELATIONS
}

\author{
Publications Order Form
}

WORKING PAPERS ONLY

\section{Please Supply}

Copies of IR Working Paper No

Copies of IR Working Paper No Copies of IR Working Paper No

Copies of IR Working Paper No Copies of IR Working Paper No

Copies of IR Working Paper No

Copies of IR Working Paper No

Copies of IR Working Paper No

Copies of IR Working Paper No.

* All Working Papers are $\$ A 5.50$

Method of Payment (please tick)

$\square$ Money Order

Cheque (made payable to: The Australian National University)

D Mastercard/Visa Card Number

Expiry Date.

Signature

For Overseas Orders: Payment by Mastercard/Visa or by Bank Draft in Australian Dollars only, payable to Australian National University.

Name/Organisation:

Postal Address:

Suburb:.

State:

Postcode:

Signature:

Date:

Please forward completed form and payment to:

RSPAS Publishing (PICS)

Research School of Pacific and Asian Studies

The Australian National University

Canberra ACT 0200 Australia

Phone: +61 26125 3269; Fax: +61 261259975

E-mail: jo.bushby@anu.edu.au

Web: http://rspas-bookshop.anu.edu.au

* Standing Orders Welcome * 